\title{
KINETICS OF OS(VIII) CATALYZED OXIDATION OF 2-PYRROLIDINE CARBOXYLIC ACID IN ALKALINE MEDIUM USING SODIUM PERIODATE AS OXIDANT: A MECHANISTIC APPROACH
}

\author{
Madhu Gupta ${ }^{1}$, Amrita Srivastava ${ }^{1}$, Sheila Srivastava ${ }^{2},{ }^{*}$, Ashish Verma ${ }^{1}$
}

https://doi.org/10.23939/chcht13.03.326

\begin{abstract}
The present paper deals with the kinetic and mechanistic investigation of Os(VIII) catalyzed oxidation of 2-pyrrolidinecarboxylic acid by sodium periodate $\left(\mathrm{NaIO}_{4}\right)$ in alkaline medium in the temperature range of 303-318 K. The experimental result shows a first order kinetics with respect to Os(VIII) and periodate while positive effect with respect to substrate i.e., 2-pyrrolidinecarboxylic acid was observed. The reaction showed negative effect for $\left[\mathrm{OH}^{-}\right]$. Negligible effect of $\mathrm{Hg}(\mathrm{OAc})_{2}$ and ionic strength of the medium was observed. The reaction is carried out in the presence of mercuric acetate as a scavenger. The reaction of sodium periodate and 2-pyrrolidinecarboxylic acid in alkaline medium shows 2:1 stoichiometry. The values of rate constants observed at different temperatures were utilized to calculate the activation parameters. A mechanism involving the complex formation between a catalyst, substrate and oxidant has been proposed. L-glutamic acid has been identified as the main oxidation product of the reaction using chromatography and spectroscopy. Based on kinetic data, the reaction stoichiometry and product analysis of the reaction a feasible mechanism has been proposed. The rate law has been derived from obtained kinetic data.
\end{abstract}

Keywords: kinetics, Os(VIII), oxidation, 2-pyrrolidinecarboxylic acid, sodium periodate, alkaline medium.

\section{Introduction}

Amino acids are the derivatives of protein in the diet or degradation of intracellular proteins is the final class of biomolecules and their oxidation makes a significant role in production of metabolic energy. Based upon the number of carbon atoms in the $\alpha$-amino acids

\footnotetext{
${ }^{1}$ Department of Chemistry, University of Lucknow, Lucknow, U.P., India

${ }^{2}$ Chemical Laboratories Feroze Gandhi College, Raebareli, U.P., India

*She_ila72@yahoo.com

(C) Gupta M., Srivastava A., Srivastava S., Verma A., 2019
}

species, they get oxidized to $\alpha$-keto glutamate, succinates, fumerate, oxaloacetate, etc. 2-Pyrrolidinecarboxylic acid (L-pro) is one among $20 \alpha$-amino acids with five-carbon atoms in pyrrolidine skeleton. This pyrrolidine ring is opened [1] by oxidation at the carbon atom most distant from the carboxylic group to produce a Schiff's base and hydrolysis of this Schiff's base produces a linear glutamic semi-aldehyde, which is further oxidized at the same carbon atom leading to glutamic acid. However, the earlier reports [2] reveal that L-pro undergoes oxidation with the cleavage of pyrrolidine ring at the nearest carbon atom from the carboxylic acid group followed by decarboxylation to produce 4-amino butanol or 4-amino butyric acid, whereas D-proline leads to keto acid. Since L-pro has a cyclic structure with an imino [3] group attached at one end by $-\mathrm{CH}_{2}$ and at the other end by $>\mathrm{CH}-\mathrm{COOH}$, the cleavage at the closest carbon atom from carboxylic group is unusual. This may also be due to the less reactivity of $\alpha$-carbon/hydrogen. Hence, the ring opening takes place at a carbon atom of far end from a carboxylic group. Moreover, when $-\mathrm{NH}_{2}$ group is not present at $\alpha$-carbon atom, there is no other driving force remaining for decarboxylation to produce butaraldehyde, butyric acid or keto acids. Some reports about the oxidation of L-pro claimed that the ring cleavage took place between $\mathrm{N}$ and $\mathrm{C}$, by retaining the $-\mathrm{NH}_{2}$ group with the main moiety without liberating ammonia, and the decarboxylation was proposed as a mechanism for the oxidation [4].

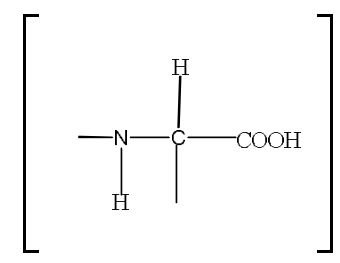

L-proline is one among non-essential amino acids and is an important component of collagen. According to [3], L-proline is considered to be the world's smallest natural enzyme and it plays an important role in catalysing the aldol condensation of acetone to various aldehydes with high stereo-specificity. 
Many transition and non-transition metal ions in their complex form are good oxidants in acidic, basic or neutral medium. However, oxidation capacity depends upon their redox potential. It is also known that the redox potential of the couple depends on the medium $\mathrm{pH}$. In recent years, the use of transition metal ion such as osmium, ruthenium and iridium as a catalyst in various redox processes has attracted considerable interest [5-6]. The mechanism of the catalysis is quite complicated because of the formation of different intermediate complexes, free radicals and different oxidation states of osmium. Although, both osmium and ruthenium belong to the same group, their compounds are stable in different oxidation states. Osmium compounds are highly stable in +8 oxidation state whereas ruthenium compounds are in +3 or +4 . Hence, their catalytic role varies to a large extent; in most of the oxidations [6, 7] of organic compounds, the reaction was independent upon substrate concentration in $\mathrm{Ru}(\mathrm{III})$ catalysis and unity or fractional order in Os(VIII) catalysis. This may be due to the large difference in their redox potentials. The redox potentials of $\mathrm{Ru}(\mathrm{IV}) / \mathrm{Ru}(\mathrm{III})$ is $+1.3 \mathrm{~V}$ which is unexpectedly higher than that of Os(VIII)/Os(VI) equal to $+0.85 \mathrm{~V}$.

Periodate is a clean and relatively selective reagent for the oxidative cleavage of organic compounds containing -hydroxy, -oxo, -amino, or -carboxyl groups. There is extensive literature on the kinetics of the periodic acid oxidation of glycols [8-9] but the kinetics of the periodate oxidation of amino alcohols [10], dicarbonyl compounds [11], and amino acids [12], has received much less attention. Oxidation with periodate has been shown to cause denaturation of proteins and inactivation of enzymes and these findings have been interpreted on the basis of periodate attack on essential amino acids. Periodate (Per) is a two electron oxidant with a redox potential of $+0.70 \mathrm{~V}$ in alkaline medium and is a more suitable reagent for the study of oxidation reactions of both organic and inorganic substrates [13]. Further we have isolated the oxidized products in a way to arrive at a suitable mechanism on the basis of kinetic and spectral results and to compute the thermodynamic quantities of various steps. An understanding of the mechanism allows the chemistry to be interpreted, understood and predicted.

\section{Experimental}

\section{1. $M$ aterials}

Reagent grade chemicals and double-distilled water (from alkaline $\mathrm{KMnO}_{4}$ in all-glass apparatus) were used. An aqueous solution of $\mathrm{NaIO}_{4}$ was prepared by dissolving $\mathrm{NaIO}_{4}$ (BDH) in water and was standardized iodometrically [14]. L-proline, a colorless crystalline compound (E-Merck) was used without further purification for the preparation of aqueous stock solution. The stock solution of Os(VIII) was obtained by dissolving osmic acid $\left(\mathrm{OsO}_{4}\right)$ (Johnson-Matthey) in $0.5 \mathrm{~mol} \cdot \mathrm{dm}^{-3}$ sodium hydroxide solution and its concentration was ascertained [15] against standard ceric ammonium sulfate solution in acid medium. Aqueous solutions of $\mathrm{NaOH}$ and $\mathrm{NaCl}$ were used to maintain the $\left[\mathrm{OH}^{-}\right]$and ionic strength, respectively. In the present investigation, the effect of concentration of $\left[\mathrm{NaIO}_{4}\right]$ was studied from $0.8 \cdot 10^{-3}$ to $5.0 \cdot 10^{-3}$ and [L-proline] was studied between $2.0 \cdot 10^{-4}$ to $1.3 \cdot 10^{-3}$. The reaction stills were blackened from outside to prevent photochemical effects.

\subsection{Kinetic Procedure}

Appropriate volumes of the solutions of substrate, $\mathrm{NaOH}, \mathrm{Hg}(\mathrm{OAc})_{2}, \mathrm{OsO}_{4}$ and the requisite volume of doubly distilled $\mathrm{H}_{2} \mathrm{O}$ were placed in the reaction vessel, which was located in an electrically operated thermostatic water bath maintained at the desired temperature within the $\pm 0.1 \mathrm{~K}$. When the mixture attained the bath temperature, the reaction was initiated by adding the required volume of $\mathrm{NaIO}_{4}$ solution, which was also placed separately in the same bath in another vessel. The kinetics of the reaction was followed by estimating the quantity of unconsumed $\mathrm{NaIO}_{4}$. An aliquot $(5 \mathrm{ml})$ of the reaction mixture was withdrawn at regular time intervals and was monitored by iodometric determination of the remaining $\mathrm{NaIO}_{4}$ up to two half lives of the reaction. The reaction rate $(d c / d t)$ in each kinetic run was determined by the slope of the tangent drawn at fixed concentrations of $\mathrm{NaIO}_{4}$ in the plots of unconsumed $\mathrm{NaIO}_{4}$ versus time. The order of the reaction with respect to each reactant was determined with the help of $(d c / d t)$ values calculated for various concentrations of each reactant. The moderately higher concentration of $\mathrm{NaOH}$ was used to maintain the $\mathrm{OH}^{-}$concentration in the reaction. Hence, the effect of dissolved $\mathrm{CO}_{2}$ on the rate was examined by carrying out the kinetics in the presence of $\mathrm{CO}_{2}$ and $\mathrm{N}_{2}$. It was found that there was no variation of rate constants which indicates that dissolved $\mathrm{CO}_{2}$ had any effect on the reaction rate.

\section{Results and Discussion}

\subsection{Determination of Stoichiometry and Product Analysis}

The stoichiometric analysis of oxidation reaction of proline with sodium periodate indicates that two moles of the oxidant react with one mole of a substrate. This result 
showed 1:2 stoichiometry according to the equation. Varying $\left[\mathrm{NaIO}_{4}\right]$ :[proline] ratios were equilibrated at $313 \mathrm{~K}$ for $72 \mathrm{~h}$ under the experimental conditions $\left[\mathrm{NaIO}_{4}\right]>>$ [proline]. Estimation of unconsumed $\left[\mathrm{NaIO}_{4}\right]$ in different sets showed that two moles of $\mathrm{NaIO}_{4}$ were consumed in order to oxidise one mole of proline. Accordingly, the following stoichiometry equation can be formulated.

The main oxidative product of L-proline was identified as L-glutamic acid by its spot test in which the intense blue color was obtained by adding ninhydrin [16]. It supports the results from the earlier work [17]. It is also estimated quantitatively as a ninhydrin derivative by spectrophotometric methods [18]. It was found that L-proline is oxidized to L-glutamic acid. Other plausible products like glutamic semialdehyde and R-keto acid were not found.

Further, L-glutamic acid was separated from the reaction mixture by an ether extract which was concentrated by evaporation and mixed with concentrated hydrochloric acid $(2 \mathrm{ml})$. The residue was then evaporated several times with water (ca. $5 \mathrm{ml}$ portions) to remove the excess of hydrochloric acid and finally with methanol $(10 \mathrm{ml})$. The white needles produced were collected, dried, and analyzed for $\mathrm{C}, \mathrm{H}, \mathrm{N}$, and $\mathrm{Cl}$ contents. The elemental analysis was consistent with that of $\mathrm{L}$-glutamate hydrochloride $\left(\mathrm{C}_{10} \mathrm{H}_{17} \mathrm{~N}_{2} \mathrm{O}_{8} \mathrm{Cl}\right.$ ). (Found: $\mathrm{C}, 40.5 ; \mathrm{H}, 7.5$; $\mathrm{N}, 8.6 ; \mathrm{Cl}, 16.6$. Calcd: C, 41.9; H, 7.3; N, 9.8; Cl, $17.2 \%)$. Further it was subjected to IR scanning. The stretching frequencies of $-\mathrm{NH} 2,-\mathrm{COOH}$ and carbonyl were found to be 3430,3060 , and $1684 \mathrm{~cm}^{-1}$, respectively, and $\mathrm{C}-\mathrm{N}$ vibration frequencies at $1124 \mathrm{~cm}^{-1}$ were also observed (Fig. 1). The product was also confirmed by UV spectrum (Fig. 2). This clearly indicates that the oxidative product of L-proline was found to be L-glutamic acid which is formed by reacting with 2 moles of $\left[\mathrm{NaIO}_{4}\right]$ as shown by Eq. (1).

\subsection{Reaction Orders}

Reaction order and the order with respect to each reactant were determined by varying the concentrations of oxidant, reductant, catalyst and alkali in turn, while keeping the other constants.

\subsection{Effect of [L-Proline]}

The dependence of reaction rate on L-proline concentration was examined over concentrations in the range of $(0.13-2.00) \cdot 10^{-3} \mathrm{~mol} \cdot \mathrm{dm}^{-3}$ at different temperatures in the range of $303-318 \mathrm{~K}$. The results in Table 1 showed that the rate constant increased with the increase in [L-proline]. It was confirmed by a plot of $\log$ [L-Pro] $v s . \log d c / d t$ (Fig. 3). Further the plot of $d c / d t$ versus [L-proline] was linear (Fig. 4), passing through the origin according to Eq. (2). The zero intercept revealed that the self decomposition of $\mathrm{NaIO}_{4}$ did not take place under the experimental conditions employed in this study.

$$
k_{o b s}=k_{2}[\text { proline }]
$$
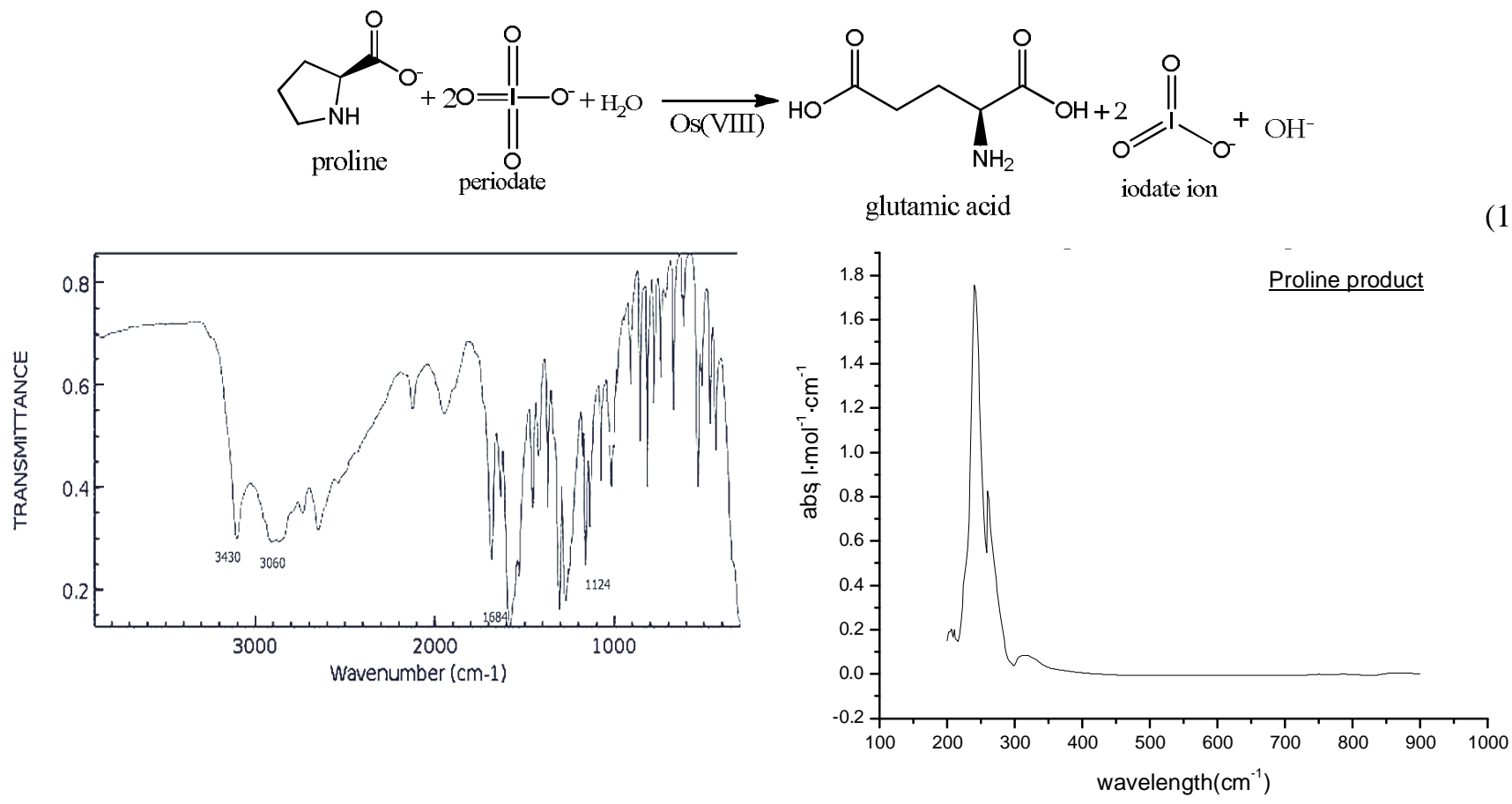

Fig. 1. IR-spectrum of the main product
Fig. 2. UV spectrum of the main product 
Table 1

Effect of [ $\left.\mathrm{NaIO}_{4}\right]$, [L-Proline], [Hg(OAc $\left.)_{2}\right][\mathrm{NaOH}]$ and $\mathrm{Os}(\mathrm{VIII})$ on oxidation of L-proline by $\mathrm{NaIO}_{4}$ catalyzed by $\mathrm{Os}(\mathrm{VIII})$ in alkaline medium at $303 \mathrm{~K}$

\begin{tabular}{|c|c|c|c|c|c|}
\hline $\begin{array}{c}{\left[\mathrm{NaIO}_{4}\right] \cdot 10^{3},} \\
\mathrm{~mol} \cdot \mathrm{dm}^{-3}\end{array}$ & $\begin{array}{l}{[\mathrm{S}] \cdot 10^{2}} \\
\mathrm{~mol} \cdot \mathrm{dm}^{-3}\end{array}$ & $\begin{array}{c}{\left[\mathrm{Hg}(\mathrm{OAc})_{2}\right] \cdot 10^{3}} \\
\mathrm{~mol} \cdot \mathrm{dm}^{-3}\end{array}$ & $\begin{array}{c}{[\mathrm{NaOH}] \cdot 10^{3},} \\
\mathrm{~mol} \cdot \mathrm{dm}^{-3}\end{array}$ & $\begin{array}{c}(-d c / d t), \\
\mathrm{mol} \cdot \mathrm{dm}^{-3} \cdot \mathrm{s}^{-1}\end{array}$ & $K_{1} \cdot 10^{2}$ \\
\hline 0.83 & 1.00 & 1.25 & 1.00 & 0.40 & 1.87 \\
\hline 1.00 & 1.00 & 1.25 & 1.00 & 0.48 & 2.10 \\
\hline 1.25 & 1.00 & 1.25 & 1.00 & 0.53 & 2.91 \\
\hline 1.67 & 1.00 & 1.25 & 1.00 & 0.78 & 3.64 \\
\hline 2.50 & 1.00 & 1.25 & 1.00 & 1.00 & 3.30 \\
\hline 5.00 & 1.00 & 1.25 & 1.00 & 1.84 & 6.10 \\
\hline 1.00 & 0.13 & 1.25 & 1.00 & 0.20 & 1.04 \\
\hline 1.00 & 0.17 & 1.25 & 1.00 & 0.21 & 1.08 \\
\hline 1.00 & 0.25 & 1.25 & 1.00 & 0.23 & 1.26 \\
\hline 1.00 & 0.50 & 1.25 & 1.00 & 0.24 & 1.40 \\
\hline 1.00 & 2.00 & 1.25 & 1.00 & 0.26 & 1.69 \\
\hline 1.00 & 1.00 & 0.83 & 1.00 & 0.33 & 1.85 \\
\hline 1.00 & 1.00 & 1.00 & 1.00 & 0.29 & 1.73 \\
\hline 1.00 & 1.00 & 1.67 & 1.00 & 0.27 & 1.86 \\
\hline 1.00 & 1.00 & 2.50 & 1.00 & 0.28 & 1.10 \\
\hline 1.00 & 1.00 & 5.00 & 1.00 & 0.30 & 1.03 \\
\hline 1.00 & 1.00 & 1.25 & 0.83 & 0.28 & 1.42 \\
\hline 1.00 & 1.00 & 1.25 & 1.25 & 0.23 & 1.34 \\
\hline 1.00 & 1.00 & 1.25 & 1.67 & 0.21 & 1.19 \\
\hline 1.00 & 1.00 & 1.25 & 2.50 & 0.20 & 1.03 \\
\hline 1.00 & 1.00 & 1.25 & 5.00 & 0.19 & 0.84 \\
\hline
\end{tabular}

Notes: $\mathrm{Os}(\mathrm{VIII})=2.63 \cdot 10^{-6} \mathrm{M},\left[\mathrm{NaIO}_{4}\right]=1.00 \cdot 10^{-3} \mathrm{M},[\mathrm{L}-$ proline $]=1.00 \cdot 10^{-2} \mathrm{M},\left[\mathrm{Hg}(\mathrm{OAc})_{2}\right]=1.25 \cdot 10^{-3} \mathrm{M}$,

$[\mathrm{NaOH}]=1.00 \cdot 10^{-3} \mathrm{M}$

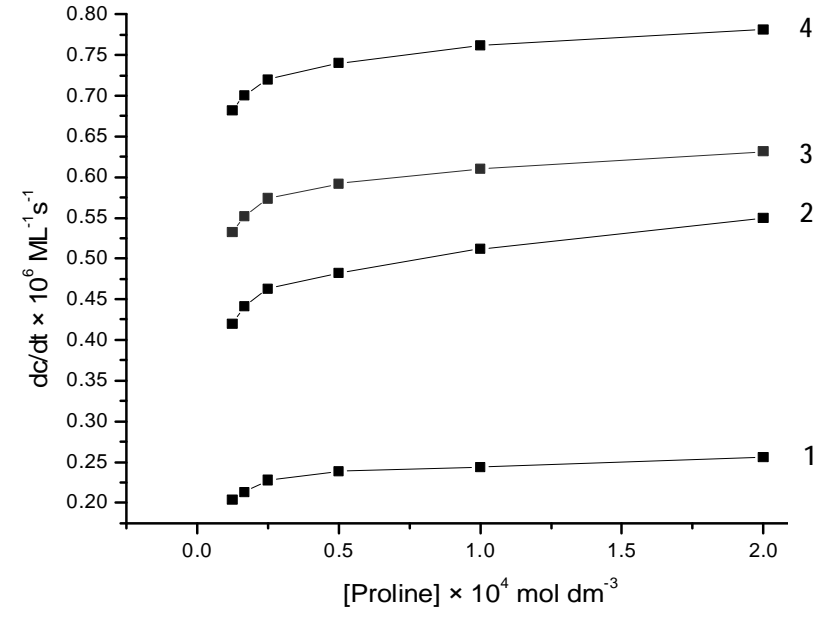

Fig. 3. Plot between rate of reaction $(-d c / d t) \cdot 10^{6} v s$.

[L-proline] $\cdot 10^{4}$ on the reaction rate at different temperatures $(\mathrm{K})$ : 303 (1), 308 (2), 313 (3) and 318 (4).

$[\mathrm{Os}(\mathrm{VIII})]=26.25 \cdot 10^{-5} \mathrm{M},\left[\mathrm{Hg}(\mathrm{OAc})_{2}\right]=1.25 \cdot 10^{-3} \mathrm{M}$, [Oxidant

$\left.\left(\mathrm{NaIO}_{4}\right)\right]=1.00 \cdot 10^{-3} \mathrm{M},[\mathrm{NaOH}]=1.00 \cdot 10^{3} \mathrm{M}$

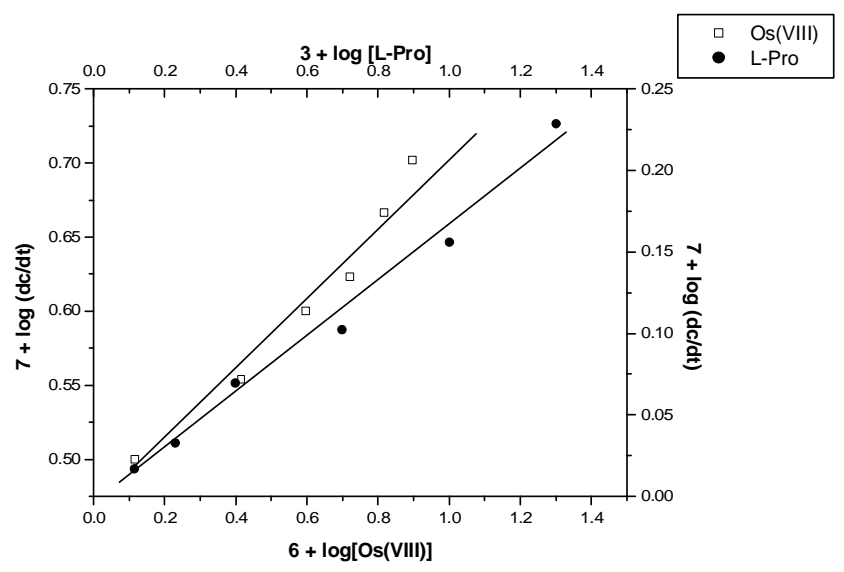

Fig. 4. Plot between rate $\log [\mathrm{Os}(\mathrm{VIII})] v s$. $\log (d c / d t)$ and $\log [$ L-Pro] $v s . \log (d c / d t)$ for oxidation of L-Pro at $308 \mathrm{~K}$ 


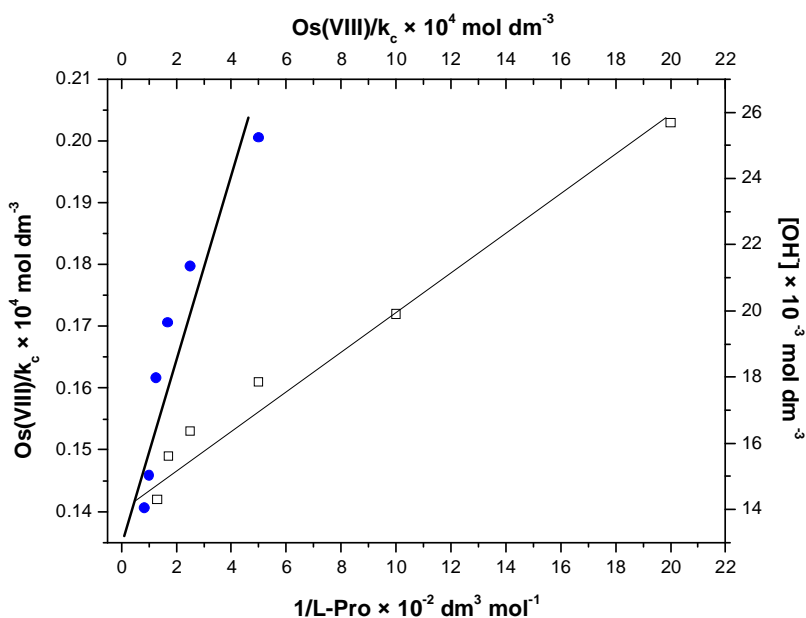

Fig. 5. Verification of rate law (5) in form of (6) for Os(VIII) catalyzed oxidation of L-proline by sodium periodate at $298 \mathrm{~K}$

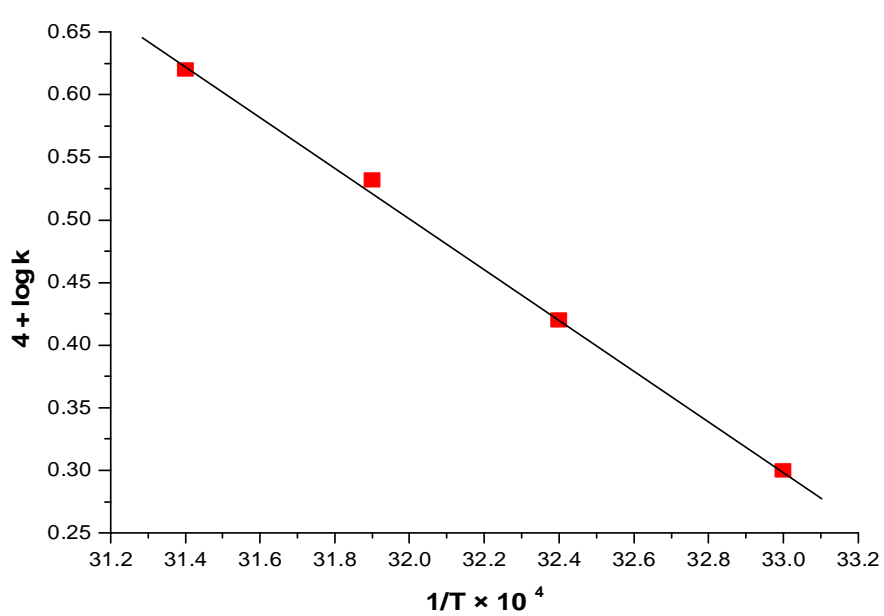

Fig. 6. Effect of temperature on rate constant for oxidation of LPro at $308 \mathrm{~K}$. $\left[\mathrm{NaIO}_{4}\right]=1.0 \cdot 10^{-3} \mathrm{~mol} \cdot \mathrm{dm}^{-3}$;

$[\mathrm{L}-\mathrm{Pro}]=1.0 \cdot 10^{-2} \mathrm{~mol} \cdot \mathrm{dm}^{-3} ; \mathrm{Os}(\mathrm{VIII})=2.6 \cdot 10^{-6} \mathrm{~mol} \cdot \mathrm{dm}^{-3} ;[\mathrm{NaOH}]$ $=1.0 \cdot 10^{-3} \mathrm{~mol} \cdot \mathrm{dm}^{-3} ;\left[\mathrm{Hg}(\mathrm{OAc})_{2}\right]=1.25 \cdot 10^{-3} \mathrm{~mol} \cdot \mathrm{dm}^{-3}$

Table 2

Activation parameters for Os(VIII) catalyzed oxidation of L-Proline by $\mathrm{NaIO}_{4}$ in alkaline medium at $303-318 \mathrm{~K}$

\begin{tabular}{|c|c|c|}
\hline Parameters & Temperature, $\mathrm{K}$ & L-Proline \\
\hline $\mathrm{k}_{1} \cdot 10^{4} \mathrm{~s}^{-1}$ & 303 & 1.96 \\
\hline $\mathrm{k}_{1} \cdot 10^{4} \mathrm{~s}^{-1}$ & 308 & 2.44 \\
\hline $\mathrm{k}_{1} \cdot 104 \mathrm{~s}^{-1}$ & 313 & 3.90 \\
\hline $\mathrm{k}_{1} \cdot 10^{4} \mathrm{~s}^{-1}$ & 318 & 3.56 \\
\hline $\log A$ & - & 14.45 \\
\hline$E_{a}^{*}, \mathrm{~kJ} \cdot \mathrm{mol}^{-1}$ & 308 & 82.93 \\
\hline$\Delta G^{*}, \mathrm{~kJ} \cdot \mathrm{mol}^{-1}$ & 308 & 71.83 \\
\hline$\Delta H^{*}, \mathrm{~kJ} \cdot \mathrm{mol}^{-1}$ & 308 & 80.35 \\
\hline$\Delta S^{*}, \mathrm{~J} \cdot \mathrm{K}^{-1} \cdot \mathrm{mol}^{-1}$ & 308 & -6.61 \\
\hline
\end{tabular}

Notes: Os $(\mathrm{VIII})=2.63 \cdot 10^{-6} \mathrm{M},\left[\mathrm{NaIO}_{4}\right]=1.00 \cdot 10^{-3} \mathrm{M}$, L-Proline $=1.00 \cdot 10^{-2} \mathrm{M},\left[\mathrm{Hg}(\mathrm{OAc})_{2}\right]=1.25 \cdot 10^{-3} \mathrm{M}$, $[\mathrm{NaOH}]=1.00 \cdot 10^{-3} \mathrm{M}$.

\subsection{Effect of Alkali Concentration}

At a fixed ionic strength of $0.5 \mathrm{~mol} \cdot \mathrm{dm}^{-3}$ and other conditions remaining constant, $\left[\mathrm{OH}^{-}\right]$was varied from 0.083 to $0.50 \mathrm{~mol} \cdot \mathrm{dm}^{-3}$. It was noticed that as $\left[\mathrm{OH}^{-}\right]$ decreases the rate of reaction was increased (Table 1). The plot of $\log [\mathrm{OH}]$ vs. $\log d c / d t$ was linear (Fig. 5). Its decreasing effect on rate is due to the variation of concentration of hydroxide species of Os(VIII) at different $\left[\mathrm{OH}^{-}\right]$. The various forms of hydroxide complexes in alkaline medium such as $\left[\mathrm{OsO}_{3}(\mathrm{OH})_{3}\right]^{-},\left[\mathrm{OsO}_{4}(\mathrm{OH})_{2}\right]^{2-}$, and $\left[\mathrm{OsO}_{5}(\mathrm{OH})\right]^{3-}$ are in equilibrium with each other.

\subsection{Effect of Temperature}

The effect of temperature on the reaction rate was studied within the range of 303-318 $\mathrm{K}$ and keeping all the other parameters at constant values. The $d c l d t$ values increased with the increase in the temperature. Plots of $1 / T$ versus $[4+\log K]$ at different temperatures were linear (Fig. 6). Thermodynamic activation parameters, associated with $k_{2} K_{1}$, were calculated using a least-squares fit to the transition state theory equation as, $\Delta H^{*}=69.0 \mathrm{~kJ} \cdot \mathrm{mol}^{-1}$ and, $\Delta S^{*}=-21.42 \mathrm{~J} \cdot \mathrm{K}^{-1} \cdot \mathrm{mol}^{-1}$ (Table 2). Both $\Delta H^{*}$ and $\Delta S^{*}$ are composite values that include formation of the precursor intermediate complex and the intramolecular electron transfer step. The reaction was endothermic as indicated from the positive value of $\Delta H^{*}$, and the intermediate was rigid as indicated from the negative value of the entropy of activation $\left(\Delta S^{*}\right)$.

\subsection{Catalytic Activity}

The variation of concentration of $\mathrm{Os}(\mathrm{VIII})$ with alkali (as shown in Fig. 2) indicates that $\left[\mathrm{OsO}_{4}(\mathrm{OH})_{2}\right]^{2-}$ is the reactive species; its concentration was varied linearly 
with [OH-]. The concentrations of the other two species, $\left[\mathrm{OsO}_{5}(\mathrm{OH})\right]^{3-}$ and $\left[\mathrm{OsO}_{3}(\mathrm{OH})_{3}\right]^{-}$are either decreased or increased drastically with various $\left[\mathrm{OH}^{-}\right]$and are not varied parallel to the variation of $d c / d t$ for different $\left[\mathrm{OH}^{-}\right]$. Hence, they are not considered as reactive species. The formation of $\left[\mathrm{OsO}_{4}(\mathrm{OH})_{2}\right]^{2-}$ is important in this study as reported earlier [19]. Each fractional order in $[\mathrm{OH}-]$ and
[L-proline] is an implicit fact to support the expectation of the pre-equilibrium before rate determining step. Firstorder in oxidant and catalyst can also be accommodated in the mechanism as shown in Scheme 1. Hence, the scheme is written in accordance with the above facts and the consideration of active species of Os(VIII) in alkali as $\left[\mathrm{OsO}_{4}(\mathrm{OH})_{2}\right]^{2-}$ in the first equilibrium step.
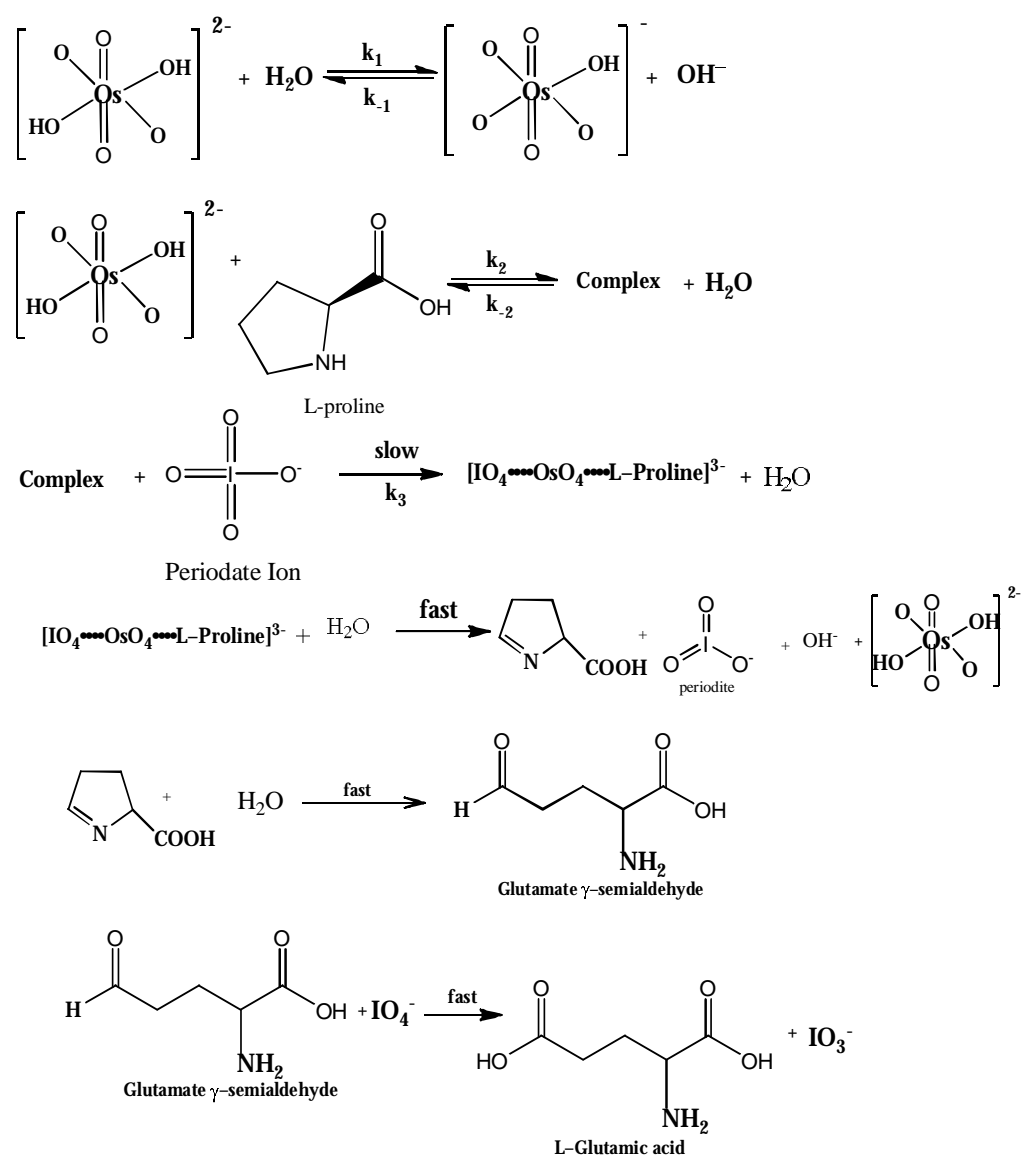

Scheme 1

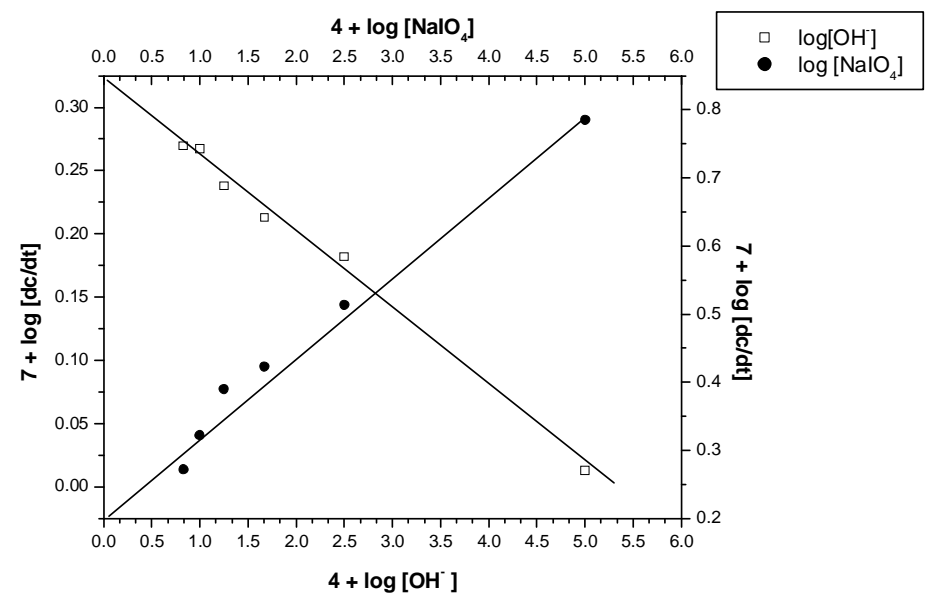

Fig. 7. Plot between $\log \left[\mathrm{OH}^{-}\right] v s . \log (d c / d t)$ and $\log \left[\mathrm{NaIO}_{4}\right] v s \cdot \log (d c / d t)$ for oxidation of L-Pro at $308 \mathrm{~K}$ 
The Lineweaver-Burk plot proved the complex formation between Os(VIII) and L-Pro, which explains fractional order in [L-Pro]. The rate law for Scheme 1 is derived as,

$$
\begin{gathered}
\text { Rate }=\frac{d\left[I O_{4}^{-}\right]}{d t} \\
\text { Rate }=\left\{\frac{k_{3} K_{2}\left[I O_{4}^{-}\right]\left[O s(V I I I)_{T}\right] \cdot[L-p r o]}{1+K_{1}\left[O H^{-}\right]+K_{2}[L-p r o]}\right\} \\
k=\frac{\text { Rate }}{\left[I O_{4}^{-}\right]}=\left\{\frac{k_{3} K_{2}\left[O s(V I I I)_{T}\right] \cdot[L-p r o]}{1+K_{1}\left[O H^{-}\right]+K_{2}[L-p r o]}\right\} \\
\frac{\left[O s(V I I I)_{T}\right.}{k}=\frac{1}{k_{3} K_{2}[L-p r o]}+\frac{K_{2}\left[O H^{-}\right]}{k_{3} K_{2}[L-p r o]}+\frac{1}{k_{3}}
\end{gathered}
$$

The rate law (5) can be rearranged to Eq. (6), which is suitable for verification.

Eq. (6) proves that, the plots of $[\mathrm{Os}(\mathrm{VIII})] / k v s$. $1 /\left[\mathrm{L}-\right.$ pro] and $[\mathrm{Os}(\mathrm{VIII})] / k$ vs. $\left[\mathrm{OH}^{-}\right]$were linear (Fig. 7). L-proline has two donor atoms, namely $\mathrm{N}$ from imino moiety and $\mathrm{O}$ from the carboxylic group, having a lone pair of electrons. It is a known [20] fact that $\mathrm{N}$ is a small potent atom and can donate a pair of electrons to the central metal ion of Os(VIII) to form an adducts. The presence of two $-\mathrm{CH}_{2}$ groups on either side of the $\mathrm{N}$ atom favours the positive charge on the $\mathrm{N}$ atom and makes it easy to form the complex. Thus, formation of a complex between $\mathrm{Os}(\mathrm{VIII})$ and $\mathrm{O}$ atom of carboxylic group can be ruled out. The adduct formed in this way with $\mathrm{N}$ might be very reactive and undergoes oxidation easily by $\mathrm{NaIO}_{4}$. This is evidenced by the fact that in the absence of Os(VIII), the reaction between L-proline and $\mathrm{NaIO}_{4}$ was not observed. Therefore, the intermediate as shown in the second step of Scheme 1 reacts with $\mathrm{NaIO}_{4}$ in the ratedetermining step to give an intermediate from L-proline. This justifies the unit order each in oxidant and catalyst. The mechanism as in Scheme 1 and rate law are verified by plotting the graphs of $\log [\mathrm{OH}-]$ and $\log [\mathrm{L}$-proline $] v s$. $\log d c / d t$ which should be linear (Figs. 4, 5). From the slopes and intercepts of such plots, the values of $k, K_{1}$, and $K_{2}$ are calculated. The $K_{1}$ found in this study is in close agreement with the reported value [19]. This justifies the formation of $\left[\mathrm{OsO}_{4}(\mathrm{OH})_{2}\right]^{2-}$.

A negative value of $\Delta S^{*} \quad\left(-6.61 \mathrm{~J} \cdot \mathrm{K}^{-1} \cdot \mathrm{mol}^{-1}\right)$ suggests that the two ionic species combine in rate determining step to give a single intermediate complex which is more ordered than the reactants [21, 22]. The smaller rate constant of the slow step of the mechanism indicates that the oxidation presumably occurs through an inner-sphere mechanism. This conclusion was supported by earlier reports [23-25].

\section{Conclusions}

Thus, in the oxidation of $\mathrm{L}$-proline by $\mathrm{NaIO}_{4}$ in alkaline media, it has been found that $\mathrm{NaIO}_{4}$ itself is the main oxidizing species, and the conjugate base of $\mathrm{L}$-proline is the main reducing species and the reaction was first-order dependent on both [proline] and $\left[\mathrm{NaIO}_{4}\right]$. L-glutamic acid was identified as the final oxidation product. Oxidation of L-proline was set-up to mimic the biological path. The reaction product was found to be L-glutamic acid. However, earlier studies reveal that the products were 4-amino butyric acid [3], 4-amino butaraldehyde [26], and keto acids [27]. The 4-amino butaraldehyde is the most unpredictable product, as L-proline oxidizes through a pyrrolidine ring cleavage without decarboxylation. If aldehyde is formed at all, it would be glutamic semialdehyde. In the absence of Os(VIII), the reaction between L-proline and $\mathrm{NaIO}_{4}$ is almost imperceptible, whereas the addition of a small amount of Os(VIII) favours the spontaneity of the reaction. This might be the reactive species of adduct, which is formed by interacting L-proline with Os(VIII). Though Os(VIII) is used as a catalyst it did not undergo reduction to Os(VI), but it catalyzes through the formation of active adduct and regenerates in the rate determining step by reacting with $\mathrm{NaOH}$.

\section{Appendix: Derivation of Rate Law for Scheme 1}

$\left.[\mathrm{Os}(\mathrm{VIII})]_{T}\right]$ is equal to the sum of concentrations:

$$
\begin{aligned}
& \frac{d\left[I O_{4}^{-}\right]}{d t}=\text { Rate }=k_{3}[\text { IOO } \\
& \text { Os }(\text { VIII })_{T}=[\text { Complex }] \\
& \frac{d\left[C_{1}\right]}{d t}=\left[C_{2}\right]+[\text { Complex }] \\
& -k_{2}\left[C_{1}\right][L-\text { pro }]+k_{-2}[\text { Complex }]
\end{aligned}
$$
we get:

On applying steady state approximation to Eq. (3)

$$
\begin{gathered}
-k_{1} \mathrm{C}_{1}\left[\mathrm{OH}^{-}\right]+k_{-1}\left[\mathrm{C}_{2}\right]- \\
-k_{2}\left[C_{1}\right][L-\text { pro }]+k_{-2}[\text { Complex }]=0
\end{gathered}
$$

Similarly we have the rate of formation of $\left[C_{2}\right]$ :

$$
\frac{d\left[C_{2}\right]}{d t}=k_{1}\left[C_{1}\right]\left[\mathrm{OH}^{-}\right]-k_{-1}\left[C_{2}\right]
$$

On applying steady state approximation to the above equation we get:

$$
\begin{gathered}
k_{1}\left[C_{1}\right]\left[\mathrm{OH}^{-}\right]-k_{-1}\left[\mathrm{C}_{2}\right]=0 \\
{\left[C_{2}\right]=\frac{k_{1}\left[C_{1}\right]\left[\mathrm{OH}^{-}\right]}{k_{-1}}}
\end{gathered}
$$

From Eqs. (4) and (6) we get:

$$
\left[C_{1}\right]=\frac{k_{-2}[\text { Complex }]}{k_{2}[L-\text { pro }]}
$$


Putting the value of $\left[C_{1}\right]$ in Eq. (7) we get:

$$
\begin{gathered}
{\left[\mathrm{C}_{2}\right]=\frac{k_{1} k_{-2}\left[\mathrm{OH}^{-}\right][\text {Complex }]}{k_{-1} k_{2}[L-\text { pro }]}} \\
{\left[C_{2}\right]=\frac{K_{1}\left[\mathrm{OH}^{-}\right][\text {Complex }]}{K_{2}[L-\text { pro }]} \quad\left\{\mathrm{Q} K_{1}=\frac{k_{1}}{k_{-1}} ; K_{2}=\frac{k_{2}}{k_{-2}}\right\}(9)}
\end{gathered}
$$

Thus from Eqs. (2), (8) and (9) we get total concentration of the catalyst, i.e.

$$
\begin{gathered}
\text { Os }(\text { VIII })_{T}=\frac{[\text { Complex }]}{K_{2}[L-\text { pro }]}+\frac{K_{1}\left[\mathrm{OH}^{-}\right][\text {Complex }]}{K_{2}[L-\text { pro }]}+ \\
+[\text { Complex }]= \\
=[\text { Complex }]\left\{\frac{1+K_{1}\left[\mathrm{OH}^{-}\right]+K_{2}[L-\text { pro }]}{K_{2}[L-\text { pro }]}\right\} \\
{[\text { Complex }]=\left\{\frac{K_{2}[L-\text { pro }]\left[O s(\text { VIII })_{T}\right]}{1+K_{1}\left[O H^{-}\right]+K_{2}[L-p r o]}\right\}} \\
\text { Rate }=\left\{\frac{k_{3} K_{2}\left[H I O_{4}^{-}\right]\left[O s(V I I I)_{T}\right][L-p r o]}{1+K_{1}\left[\mathrm{OH}^{-}\right]+K_{2}[L-p r o]}\right\}
\end{gathered}
$$
kinetics.

The rate law is in agreement with all observed

\section{References}

[1] Nelson D., Cox M.: Lehninger Principles of Biochemistry, 4th edn. W.H. Freeman and Co., New York 2007.

[2] Hiremath C., Kiran T., Nandibewoor S.: J. Mol. Catal. A., 2006, 248, 163. https://doi.org/10.1016/j.molcata.2005.12.018

[3] Seregar V., Hiremath C., Nandibewoor S.: J. Phys. Chem., 2006, 220, 615. https://doi.org/10.1524/zpch.2006.220.5.615

[4] List B., Lerner R., Barbes C.: J. Am. Chem. Soc., 2000, 122, 2395. https://doi.org/10.1021/ja994280y

[5] Das A.: Coord Chem., 2001, 213, 307.

https://doi.org/10.1016/S0010-8545(00)00376-3

[6] Srivastava S., Patel R.: World J. Pharm. Pharm. Sci., 2014, 3, 365.

[7] Gupta M., Srivastava S.: Bull. Catal. Soc. India, 2015, 14, 1.

[8] Vijayasri K., Rajaram J., Kuriacose J.: J. Chem. Sci., 1985, 95, 573.

[9] Duk F.: J. Am. Chem. Soc., 1947, 69, 3054.

https://doi.org/10.1021/ja01204a038

[10] Buistc G., Bunton A., Hipperson W.: J. Chem. Soc. B, 1971,

2128. https://doi.org/10.1039/J29710002128

[11] Maros L., Molnar-Perel I., Schissel E., Szerdahelyi V.: J. Chem.

Soc. Perkin Trans., 1980, 11, 39.

https://doi.org/10.1039/P29800000039

[12] Dahlgre G., Reed K.: J. Am. Chem. Soc., 1967, 89, 1380.

https://doi.org/10.1021/ja00982a018

[13] Rao M., Sethuram B., RaoN.: J. Indian Chem. Soc., 1980, 57, 149.

[14] Rao D., Sridevi M., Vani P.: Indian J. Appl. Res., 2013, 3, 585.

[15] Mendham J., Denney R., Barnes J., Thomas M.: Vogel's Text

Book of Quantitative Chemical Analysis, $6^{\text {th }}$ edn. Pearson Education, Delhi 2003.
[16] Tuwar S., Nandibewoor S., Raju J.: Trans. Met. Chem., 1991, 16, 430. https://doi.org/10.1007/BF01129458

[17] Feigl F.: Spot Tests in Organic Analysis. Elsevier, New York 1975.

[18] Nelson D., Cox M.: Lehningers, Principles of Biochemistry, $4^{\text {th }}$ edn. Freeman and Co., New York 2007.

[19] Wilson K., Walker J.: Practical Biochemistry, $5^{\text {th }}$ edn. Cambridge University Press, Cambridge 2005.

[20] Devendra M., Gupta Y.: J. Chem. Soc., Dalton Trans., 1977, 1085. https://doi.org/10.1039/DT9770001085

[21] Sethuram B.: Some Aspects of Electron Transfer Reactions Involving Organic Molecules. Allied Publ. Ltd., Mumbai 2003. [22] Laidler J.: Chemical Kinetics, $3^{\text {rd }}$ edn. Pearson Education Ptc. Ltd., New Delhi 2004.

[23] Upadhyay S., Agrawal M.: Indian J. Chem., 1977, 15A, 709.

[24] Sutin N.: Annu. Rev. Phys. Chem., 1966, 17, 119. https://doi.org/10.1146/annurev.pc.17.100166.001003

[25] Lancaster M., Murray R.: J. Chem. Soc. A, 1971, 2755. https://doi.org/10.1039/J19710002755

[26] Martinez M., Pitarque M., Eldik R.: J. Chem. Soc., Dalton Trans., 1996, 2665. https://doi.org/10.1039/dt9960002665

[27] Shettar R., Hiremath M., Nandibewoor S.: Electron. J. Chem., 2005, 9, 91.

[28] Upadhyay S.: Int. J. Chem. Kinet., 1983, 15, 669.

https://doi.org/10.1002/kin.550150708

Received: March 05, 2018/Revised: March 28, 2018 / Accepted: August 30, 2018

\section{КІНЕТИКА ОКИСНЕННЯ 2-ПІРОЛІДИНКАРБОНОВОЇ КИСЛОТИ В ПРИСУТНОСТІ КАТАЛІЗАТОРА Оs(VIII) В ЛУЖНОМУ СЕРЕДОВИЩІ 3 ВИКОРИСТАННЯМ ПЕРІОДАТУ НАТРІЮ: МЕХАНІСТИЧНИЙ ПІДХІД}

Анотація. Проведено кінетичні та механічні дослідження окиснення 2-піролідинкарбонової кислоти, періодатом натрію (NaIO4) в лужному середовищі в діапазоні температур 303-318 K в присутності каталізатора Os(VIII). Визначено, щзо реакція є першого порядку відносно Os(VIII) та періодату. Спостерігається позитивний ефект відносно субстрату, тобто 2-піролідинкарбонової кислоти, негативний вплив на $\left[\mathrm{OH}^{-}\right]$i незначний вплив $\mathrm{Hg}(\mathrm{OAc})^{2}$ та йонної сили середовища. Встановлено стехіометрію реакиії між періодатом натрію та 2-піролідинкарбоновою кислотою в лужному середовищі (2:1). 3 використанням констант ивидкості за різних температур розраховано енергію активації. Запропоновано механізм, ше передбачає утворення комплексу між каталізатором, субстратом та оксидантом. Хроматографічними та спектроскопічними методами визначено, щуо основним продуктом окиснення є L-глутамінова кислота. На підставі кінетичних даних, стехіометрії та аналізу продуктів реакиії запропоновано можливий механізм реакції. На основі отриманих кінетичних даних виведені кінетичні рівняння.

Ключові слова: кінетика, Os(VIII), окиснення, 2-піролідинкарбонова кислота, періодат натрію, лужне середовище. 